\title{
Water requirement of irrigated and rainfed crops
}

\begin{abstract}
Irrigated agriculture has been showing considerable levels of evolution over the last few years, in addition to showing a relevant option for food production. Alternative methods and technologies have been developed for the rational use of water in the field to be used also by small producers, with the aim of increasing productivity in the crops worldwide. It is known that for the proper management of irrigation it is necessary to determine the reference evapotranspiration, ETo. Evapotranspiration consists of a combined process of heat transfer and mass, in the form of vapor, from a vegetated surface to the atmosphere, covering the direct evaporation of soil and plant surfaces and the transpiration of plants. Considering this concept, soon there were difficulties in its use, checking the need for standardization. The ETo is defined as evapotranspiration of a hypothetical crop covering the whole soil, in active growth, without water or nutritional restriction, with a mean height of $0.12 \mathrm{~m}$, surface resistance of $70 \mathrm{sm}^{-1}$ and albedo of 0.23 . The ETo can be calculated using direct methods: drainage lysimeters, mechanical / electronic weighing, and flotation, field experimental plots method, soil moisture control, "Input - Output" method. Among the various methods for estimating ETo are FAO-24 Radiation, Priestley-Taylor, FAO-24 Blaney-Criddle, Hargreaves-Samani, Camargo-71 and FAO Penman Monteith, standard method considered by FAO. The determination of ETo is a complex nonlinear process, depending on the interaction of several climatological variables, such as air temperature, humidity, wind speed, radiation, as well as the growth stage of the crop. For this reason, several studies with crops of great commercial value, such as corn, tomato, sugarcane, soybean, wheat and cotton, have been developed applying the different methods to determine the ETo, considering different situations.
\end{abstract}

Volume 2 Issue 3 - 2018

\author{
Priscilla Tavares Nascimento,' Gustavo \\ Franco de Castro, ${ }^{2}$ João Carlos Ferreira \\ Borges Júnior ${ }^{3}$ \\ 'Department of Plant Science, Federal University of Lavras, \\ Brazil \\ ${ }^{2}$ Department of Soils, Federal University of Viçosa, Brazil \\ ${ }^{3}$ Department of Agrarian Sciences, Federal University of São \\ João Del Rei, Brazil
}

Correspondence: Gustavo Franco de Castro, Departamento de Solos, Universidade Federal de Viçosa, Brazil, Email gustavofcastro@ymail.com

Received: May 01, 2018 | Published: June 042018

\section{Introduction}

Over time, man has been perfecting his agricultural practices with the aim of increasing production in his crops, improving his knowledge in order to develop plant species that produce the maximum in the environment where they are cultivated. However, even managing to control the various variables in the field, such as fertility, pathogens, pest attacks, invasive plants, among others, there is still one that cannot be controlled, the climate. History shows us that irrigation was seen not only as a tool in the struggle against water scarcity, but as a factor of wealth and prosperity, so much so that large agglomerations settled on the banks of the Huang Ho and Iang-tse-Kiang rivers, river Nile, Tigre, Euphrates and Gange. ${ }^{1}$ Water in particular has been a major concern for farmers, since in certain regions, mainly in Brazil, this is often scarce, compromising the maximum development of crops and even causing great losses for the producer. $\mathrm{T} \mathrm{h} \mathrm{u} \mathrm{s}$, several studies, methodologies and technologies to estimate the water needs of the crops in different locations around the world have been developed in order to determine the amount of water required by a crop and the expected response to its application. These methodologies are closely associated with edaphic factors, agronomic and, mainly, climatic conditions.

In order to carry out an irrigation planning it is possible to determine the effect of the amount of water applied in response to the crop, that is, the production. Water stress can be determined by analyzing the relationship between actual evapotranspiration (ETr) and maximum evapotranspiration (ETm). If the water requirement is not met the growth and consequent yield will certainly be affected. The way in which the water deficit affects crop growth and yield varies according to the species and its phenological stage. ${ }^{2}$ According to Albuquerque, ${ }^{3}$ the water required for a given crop is equivalent to potential evapotranspiration (usually symbolized by ETp or ETc, being the variable symbolism in the technical literature), free of disease and developing in a location in optimal soil conditions and climate. The optimum soil condition consists of the level of fertility and humidity sufficient for the crop to reach its potential production in the considered medium. The water requirement of a crop is based on its evapotranspiration (ETc) and is usually expressed in millimeters per day ( $\mathrm{mm} /$ day). Obtaining climatic data necessary for the estimation of water demand can be made from measurements made directly in the field. There are several published works referring to the water requirement of crops. One can mention the study of the water requirement of sugarcane, a crop that is used as raw material in several sectors of industry. The water requirement of this crop is influenced by variables related to the environmental conditions, agricultural techniques, planting period and cultivars, usually reducing with the succession of the cultivation cycles (cane-plant, cane-soca and resoca). As a result, the water requirement of the sugarcane crop tends to show large variations among the production regions. ${ }^{4}$ The most widespread methods to establish irrigation management require the determination of reference evapotranspiration, ETo. The level of accuracy to be achieved is closely linked to the choice of method, time scale and nature of climatological data.

In 1948, a landmark in the history of the irrigation area was sealed, with studies by Warren Thornthwaite and Penman, where indeed the term evapotranspiration was defined and to this day is used. Since the 1950 s, studies using simple methodologies, such as the construction of lysimeters and evaporimeter tanks, were initiated worldwide, aiming to correlate the evaporation of water on a free surface with the evapotranspiration of several crops. Today there are methods and equipment widely used to indirectly determine evapotranspiration. Among the evaporimeters used for this purpose, the Class "A" tank, which is widely used in Brazil, stands out because of its easy handling and low cost. This method provides a measure of the conjugate effect of radiation, wind, temperature and relative humidity on the evaporation of a water-free surface, so that plants have, in principle, 
a similar response to these climatic variables, as well as other factors which can produce different effects on the loss of water by the crop. ${ }^{5}$

In order to relate the evaporation of the tank water with the reference evapotranspiration a coefficient is used, which takes into account the climate and the environment where the tank is located. Thus, the calculation of ETo through the Class A Tank is performed by means of the equation:

$$
E T o=K p \times E C A
$$

On what,

ETo-Reference evapotranspiration ( $\mathrm{mm} /$ day);

Kp-Tank coefficient (dimensionless);

ECA-Evaporation of water from the Class A tank ( $\mathrm{mm} /$ day).

Evapotranspiration consists of a combined process of heat transfer and mass, in the form of vapor, from a vegetated surface to the atmosphere, covering the direct evaporation of soil and plant surfaces and the transpiration of plants. ${ }^{6}$ considering this concept; soon there were difficulties in its use, checking the need for standardization. According to Allen et al., ${ }^{7}$ the reference evapotranspiration (ETo) is defined as evapotranspiration of a hypothetical crop covering the whole soil, in active growth, without water or nutritional restriction, with a mean height of $0.12 \mathrm{~m}$, surface resistance of $70 \mathrm{sm}^{-1}$ and albedo of 0.23 .

The reference evapotranspiration can be calculated using direct methods, from equipment such as lysimeters (vegetated tanks). Examples of direct methods are: drainage lysimeters, mechanical / electronic weighing, and flotation, field experimental plots method, soil moisture control, "Input - Output" method. Among the methods classified as indirect, besides the tanks already mentioned, and other types of evaporimeters, there is the use of equations, with different data requirements. Some equations are based on radiation data (eg FAO24 Radiation and Priestley-Taylor); others are based on temperature data (eg FAO-24 Blaney-Criddle, Hargreaves-Samani, Camargo-71). However, equations can combine the effects of radiation, temperature, air humidity and wind speed, as in the FAO Penman-Monteith method. ${ }^{7}$ Numerous equations for the determination of ETo have been developed, many of them frequently used, others not so much, due to the great demand of meteorological data, which are not usually available to the small producer. After calculating ETo using any of these methods, this value is multiplied by a crop coefficient $(\mathrm{Kc})$, where crop evapotranspiration (ETc) is obtained. The technical literature on these approaches is vast, with Doorenbos \& Pruitt, ${ }^{8}$ Jensen et al., ${ }^{9}$ Sediyama, ${ }^{10}$ Camargo \& Camargo, ${ }^{11}$ Vega \& Jara, ${ }^{12}$ among others. Currently, agriculture in Brazil has been reaching increasingly higher production levels in irrigated or rainfed systems; hence the need to improve techniques in agricultural production systems, so as to improve the safety of crop production and reduce the volume of water applied. Reliable estimates of water use are indispensable for the sustainability of the production system, since they tend to reduce nutrient leaching and soil degradation. ${ }^{4}$

\section{Main indirect methods of estimating ETo \\ FAO method 24 radiation}

According to ${ }^{8}$ in those regions where observations of sunshine, cloudiness or radiation and air temperature are available, but there are no data on humidity and winds, it is suggested that the use of the radiation method to estimate climatic effects on the water needs of crops.

$$
E T o=a+b(W \times R s)
$$

On what,

ETo-Reference evapotranspiration, $\mathrm{mm}$ /day;

Rs-Solar radiation expressed in evaporative equivalent, $\mathrm{mm}$ /day;

W-Temperature and altitude dependent weighting index;

a\&b-Coefficients of the line, whose values, depend on the general levels of humidity and winds.

\section{FAO 24 blaney-criddle}

To better define the effects of climate on crop water requirements, the Blaney \& Criddle ${ }^{13}$ method considers general levels of minimum relative humidity, wind speed and sunshine.

$$
E T o=a_{B C}+b_{B C} f
$$

On what,

$a_{B C}$-linear coefficient of the relationship between ETo and $\mathrm{f}, \mathrm{mm}$ / day;

$\mathrm{b}_{\mathrm{BC}}$-angular coefficient of the relationship between ETo and $\mathrm{f}$;

f-consumptive use factor (product $\mathrm{b}_{\mathrm{BC}}$ f has unit $\mathrm{mm} /$ day).

The consumptive use factor is obtained through the equation.

$$
f=p\left(0,46 T_{\text {med }}+8,13\right)
$$

On what,

p-Percentage of annual daytime hours during the period considered;

$\mathrm{T}_{\text {med }}$-average daily air temperature ${ }^{\circ} \mathrm{C}$.

\section{Hargreaves-samani method}

The Hargreaves-Samani method has been successfully used in some places to estimate ETo in situations where some climatic data are not available.

$$
\text { ETo }=0,0023 R_{a}\left(T_{\max }-T_{\min }\right)^{0,5}\left(T_{\text {med }}+17,8\right)
$$

On what,

$\mathrm{R}$-Solar radiation at the top of the atmosphere, expressed in $\mathrm{mm}$ of equivalent evaporation per day;

$\mathrm{T}_{\max }$-maximum daily air temperature, ${ }^{\circ} \mathrm{C}$;

$\mathrm{T}_{\min }$-minimum daily air temperature, ${ }^{\circ} \mathrm{C}$;

$\mathrm{T}_{\text {med }}$-Average daily air temperature, ${ }^{\circ} \mathrm{C}$.

\section{Priestley-taylor method}

The equation used in the Priestley-Taylor method developed in Australia has the following form. ${ }^{7,9}$

$$
\text { ETo }=1,26 \frac{\Delta}{\Delta+\gamma}(R n+G)
$$


On what,

$\Delta$-Slope of saturation vapor pressure curve, $\mathrm{kPa}^{\circ} \mathrm{C}^{-1}$;

$\gamma$-Psychrometric constant, $\mathrm{kPa}^{\circ} \mathrm{C}^{-1}$;

Rn-radiation balance on the crop surface, $\mathrm{MJ} \mathrm{m}^{-2} \mathrm{day}^{-1}$;

G-Soil heat flux density, $\mathrm{MJm}^{-2}$ day ${ }^{-1}$

\section{FAO penman-monteith method}

This method is considered standard by the FAO, applicable to the evaluation of other methods. It is based on several physical and chemical principles in the soil-plant-atmosphere system. ${ }^{7}$

$$
\text { ETo }=\frac{0,408 \Delta\left(R_{n}-G\right)+\gamma \frac{900}{T_{m e d}+273} U_{2}\left(e_{s}-e_{a}\right)}{\Delta+\gamma\left(1+0,34 U_{2}\right)}
$$

On what,

$\mathrm{T}_{\text {med }}$-Average air temperature taken at $2 \mathrm{~m}$ height, ${ }^{\circ} \mathrm{C}$;

$\mathrm{U}_{2}$-wind speed taken at $2 \mathrm{~m}$ height, $\mathrm{ms}^{-1}$; saturation pressure of water vapor, $\mathrm{kPa}$; and - the current vapor pressure, $\mathrm{kPa}$;

(es-ea)-vapor pressure deficit, $\mathrm{kPa}$;

$\Delta$ - slope of saturation vapor pressure curve, $\mathrm{kPa}^{\circ} \mathrm{C}^{-1}$;

$\gamma$ - psychrometric constant, $\mathrm{kPa}^{\circ} \mathrm{C}^{-1}$.

The determination of ETo is a complex nonlinear process, depending on the interaction of several climatological variables, such as air temperature, humidity, wind speed, radiation, as well as the growth stage of the crop. For this reason, several studies with crops of great commercial value, such as corn, tomato, sugarcane, soybean, wheat and cotton, have been developed applying the different methods to determine the ETo, considering different situations.

\section{Important concepts}

For the study of the water demand of crops, some concepts must be known with a view to greater dominance and understanding. These concepts are discussed below.

\section{Coefficient of cultivation(Kc)}

The crop coefficient (Kc) is obtained by the relation between potential crop evapotranspiration (ETp) and reference evapotranspiration (ETo). This coefficient is related to the phenological stage of the crop and varies according to its growth and development. $\mathrm{Kc}$ depends on leaf area, architecture (aerial part and root system), plant cover and plant transpiration. ${ }^{14}$ This coefficient can be obtained by the following equation:

$$
K c=\frac{E T p}{E T o}
$$

On what,

Kc-Cultivation coefficient, $\mathrm{mm}$

ETp-Potential crop evapotranspiration;

ETo-Reference evapotranspiration.

\section{Availability factor(f)}

The soil water availability factor is a parameter that limits the part of the available water of the soil that the plant can use without causing greater damages to the productivity. It is also a safety factor that has its proportion defined according to the economic value and the sensitivity of the crop to the water deficit. It also depends on the evapotranspirometric demand. ${ }^{7}$

\section{Response factor (Ky)}

For Doorenbos \& Kassam, ${ }^{2}$ the crop response in yield to water supply is quantified by the crop response factor, $(\mathrm{Ky})$, which relates the relative yield drop $(1-\mathrm{Yr} / \mathrm{Ym})$ to the relative evapotranspiration deficit (1 - ETr/ETm). According to the authors, the relation between relative yield $(\mathrm{Yr} / \mathrm{Ym})$ and relative evapotranspiration $(\mathrm{ETr} / \mathrm{ETm})$ is linear and valid for water deficits up to about $50 \%$. The response factor is variable depending on the different stages of development of the crop (establishment, vegetative, flowering, fruit formation, maturation and harvest). In order to quantify the effect of water stress on the plant, it is necessary to infer the relation between productivity decrease and evapotranspiration deficit, which involves the crop response coefficient (Ky) and is expressed by the equation. ${ }^{7}$

On what,

$$
\left(1-\frac{Y r}{Y m}\right)=K y\left(1-\frac{E T r}{E T m}\right)
$$

Yr-Actual yield obtained, $\mathrm{kg} \mathrm{ha}^{-1}$;

Ym-maximum yield obtained, $\mathrm{kg} \mathrm{ha}^{-1}$;

Ky-culture response factor, dimensionless;

ETr-real evapotranspiration, $\mathrm{mm}$;

ETm-maximum evapotranspiration, $\mathrm{mm}$.

\section{Field capacity (CC)}

Corresponds to the situation of maximum amount of water that a soil can retain under normal field conditions. It may be expressed based on the water content on a weight or volume basis. In a deep water table condition, the field capacity corresponds to the soil condition in which, after being saturated, there is a drastic reduction of the vertical movement of the water downwards, due to the reduction of the hydraulic conductivity in response to the lower soil moisture. It is higher in clayey soils, because they have a finer texture and in soils that have a high humus content and much lower in sandy soils. ${ }^{15}$

\section{Permanent Murcha Point (PMP)}

According to Briggs \& Shantz ${ }^{16}$, the permanent wilting point can be defined as the soil moisture in which the plants are induced to a wilting condition from which they do not recover the turgidity even in a saturated air environment. Corresponds to the lower limit of available water in the soil for the plants.

\section{Potential evapotranspiration (ETp)}

It is the evapotranspiration of a given crop when it has excellent conditions of field humidity. In comparing short-cycle plants under normal growing conditions, ETp is lower than potential reference evapotranspiration. ${ }^{1}$

\section{Actual evapotranspiration (ETR)}

Amount of water transferred to the atmosphere by evaporation and transpiration, under the real conditions of atmospheric factors and soil moisture. Actual evapotranspiration is equal to or less than potential evapotranspiration $(\mathrm{ETR}<\mathrm{ETp})$. 


\section{Conclusion}

It is known that for the proper management of irrigation it is necessary to determine the reference evapotranspiration, ETo. Among the various methods for estimating ETo are FAO-24 Radiation, Priestley-Taylor, FAO-24 Blaney-Criddle, HargreavesSamani, Camargo-71 and FAO Penman Monteith, standard method considered by FAO. Based on this concept and on computational modeling, simulations have been carried out correlating the volume of water applied with the crop response in terms of productivity. These simulators consider different crops, surrounded by different agricultural practices, different types of soils in different localities.

\section{Acknowledgement}

None.

\section{Conflict of interest}

The author declares there is no conflict of interest.

\section{References}

1. Bernardo S, Soares AA, Mantovani EC. Manual de irrigação. 8th ed. Rev Atualizada e ampliada, Viçosa: UFV; 2008. p. 625.

2. Doorenbos J, Kassam AH. Efeito da água no rendimento das culturas. Campina Grande: FAO; 1994. p. 306.

3. Albuquerque PEP. Requerimento de água das culturas para fins de manejo e dimensionamento de sistemas de irrigação localizada. Circular Técnica, EMBRAPA, Sete Lagoas. 2000;1:1-76.

4. Silva Thieres GF, Requerimento hídrico e coeficiente de cultura da canade-açúcar irrigada no semiárido brasileiro. Rev bras eng agríc Ambient. 2012;16(1):64-71.
5. Albuquerque PEP, Maeno P. Requerimento de água das culturas para fins de dimensionamento e manejo de sistemas de irrigação localizada. Circular Técnica. EMBRAPA, Sete Lagoas. 2007;1:1-76.

6. Maeno P, Gomide RL. Requerimento de água pelas culturas. Brasília: EMBRAPA Informação Tecnológica. 2008;277-252.

7. Allen RG, Pereira LS, Raes D, et al. Crop evapotranspiration: Guidelines for computing crop water requirements. Rome: FAO. 1998;1-15.

8. Doorenbos J, Pruitt WO. Necessidades Hídricas das culturas. Campina Grande: FAO. 1975;204.

9. Jensen ME, Burman RD, Allen RG. Evapotranspiration and irrigation water requirements. New York: American Society of Civil Engineers. 1990:360.

10. Sediyama GC. Estimativa da evapotranspiração: histórico, evolução e análise crítica. Revista Brasileira de Agrometeorologia. 1996;4(1):i-xii.

11. Camargo AP, Camargo MBP. Uma revisão analítica da evapotranspiração potencial. Bragantia, Campinas. 2000;59(2):125-37.

12. Vega EC, Jara JC. Estimación de la evapotranspiración de referencia para dos zonas (Costa y Región Andina) del Ecuador. Engenharia Agrícola, Jaboticabal. 2009;29(3):390-403.

13. Blaney HF, Criddle WD. Determining water requirements in irrigated areas from climatological and irrigation data. Washington: United States Department of Agriculture Soil Conservation Service. 1950;48.

14. Allen RG, Smith M, Pereira A, et al. An update for the definition of reference evapotranspiration. ICID Bulletin. 1994;43(2):93.

15. Ferreira LGR. Fisiologia Vegetal: Relações Hidricas. 1st ed. Fortaleza: Edições UFC. 1992;138.

16. Briggs LJ, Shantz HL. The wilting coefficient for different plants and its indirect determination. Washington DC: Department of Agriculture, Bureau of Plant Industries. 1912;53(1):20-37. 